\title{
Notes
}

\section{State and Federal Land Use Regulation: An Application to Groundwater and Nonpoint Source Pollution Control}

\author{
James C. Buresh
}

Groundwater contamination and nonpoint source pollution of ground and surface waters are two of the most significant environmental problems of the 1980's. ${ }^{1}$ Although largely ignored in existing water pollution legislation, federal ${ }^{2}$ and state $^{3}$ attention to these problems has increased substantially in recent years. Nevertheless, because both types of pollution are intimately related to land use, Congress and state governments are reluctant to regulate them: Land use is commonly considered a purely local concern.

This Note argues that this reluctance is no longer justified. In recent years, many states have recognized the inadequacies of local land use regulation, particularly in the environmental context. Local underregulation, by encouraging or tolerating harmful land uses, has adverse regional environmental consequences. Moreover, it may cause regional economic harm

1. See Tarlock, Prevention of Groundwater Contamination, 8 Zoning \& Plan. L. ReP. 121, 121 (1985) (groundwater pollution); 15 ENv'T REP. (BNA) 296 (1984) (Milwaukee Mayor Henry W. Maier: nonpoint pollution "might be the biggest environmental problem we are facing today;" Rep. Robert W. Edgar (D-Pa): nonpoint pollution is "the most important water issue we face in the 1980s and 1990s").

2. The Safe Drinking Water Act Amendments of 1986 contain a voluntary, experimental program which represents the first attempt by Congress to delineate a comprehensive groundwater protection scheme. The Safe Drinking Water Act Amendments of 1986, Pub. L. No. 99-339 (signed into law June 19, 1986, Statement on Signing S. 124 Into Law, 22 WeEkLY Comp. Pres. Doc. 831 (1986)). Proposed drafts of the Clean Water Act Amendments of 1986 have included a special nonpoint source pollution control program. See S. 1128, 99th Cong., 1st Sess. sec. 112, § 319, 131 Cong. Rec. H6107-09 (daily ed. July 23, 1985).

3. See Environmental. Law Institute, Air and Water Pollution Control Law: 1982, at 528 (1982) (nonpoint pollution); V. Pye, R. Patrick \& J. Quarles, Groundwater ContamiNATION IN THE UNITEd States 11 (1983) (groundwater). 
by creating a favorable regulatory climate that attracts desirable development from more carefully regulated communities. Local overregulation, by diverting land uses to less environmentally suitable sites, also has adverse regional environmental consequences. In addition, it may operate to exclude or restrict essential land uses, such as lower income housing, to the socioeconomic detriment of the region. This Note demonstrates that the legal doctrines and policy approaches which states have developed to deal with these problems can and should be applied to groundwater and nonpoint source pollution control. And because the federal water pollution control effort cannot succeed without effective control of groundwater and nonpoint source pollution, this Note further argues that federal water pollution control legislation must explicitly encourage and direct state regulation of defects in the local land use decisionmaking process.

\section{The Regulatory Problem}

Groundwater and nonpoint source pollution problems are distinguished by their intimate relation to land use. Groundwater is subsurface water "that occurs in permeable saturated strata of rock, sand, or gravel called aquifers." Aquifers are recharged primarily by the filtration of precipitation or surface water through recharge zones-those portions of the land surface composed of especially permeable soils. ${ }^{5}$ Most groundwater contamination originates from the land surface.

Nonpoint source pollution-pollution from diffuse sources ${ }^{6}$-threatens both ground and surface water quality. ${ }^{7}$ As with groundwater contamination, most nonpoint source pollution emanates from the land surface, usually in the form of runoff or seepage.

Waste disposal sites are the source of much groundwater and nonpoint pollution. ${ }^{8}$ However, land uses not devoted to waste disposal are a very

4. V. Pye, R. Patrick \& J. Quarles, supra note 3, at 2.

5. See Tripp \& Jaffe, Preventing Groundwater Pollution: Towards a Coordinated Strategy to Protect Critical Recharge Zones, 3 HARv. EnvTL. L. Rev. 1, 3 (1979).

6. Nonpoint source pollution can be defined as all water pollution that does not derive from a point source. A point source is any "discernible, confined and discrete conveyance," such as a pipe, ditch, well, or container, from which pollutants may be discharged. Clean Water Act $\S 502(14), 33$ U.S.C. $\S 1362(14)$ (1982).

7. See Conservation Foundation, State of the Environment: An Assessment at MidDecade 123 (1984); V. Novotny \& G. Chesters, Handbook of Nonpoint Pollution 269 (1981).

8. See L. Ortolano, Environmental Planning and Decision Making 397 (1984) (nonpoint pollutants related to waste disposal include "discharges from solid waste disposal sites, and wastewaters from septic tanks, cesspools, and industrial lagoons") (footnote omitted); Pye \& Kelley, The Extent of Groundwater Contamination in the United States, in GroundWaTER ConTAMINATION 23, 24 (Geophysics Study Comm. ed. 1984) (sources of groundwater pollution related to waste disposal include landfills, septic tanks, industrial impoundments, and deep-well waste injection). 
common cause of equally serious but less obvious groundwater and nonpoint source pollution problems. ${ }^{9}$

\section{A. The Regulatory Differential}

The national water pollution control effort, directed primarily by the Clean Water Act (CWA), ${ }^{10}$ presently focuses on the most visible and easily regulated form of pollution-point source discharges into surface waters. ${ }^{11}$ To control these discharges, CWA sets forth an extensive, federally enforceable system of effluent and ambient standards designed to be administered primarily by the states. ${ }^{12}$ Section $208,{ }^{13}$ which focuses on regional planning requirements for the construction of federally funded waste treatment facilities, contains CWA's only program for groundwater and nonpoint source pollution control. ${ }^{14}$ But these provisions merely require states to identify existing problems and develop measures for their control. Federal enforcement of this vague directive is limited to denial of CWA planning grants ${ }^{15}$ or withdrawal of EPA approval of a state's point source discharge permit program. ${ }^{16}$

This wide regulatory differential is difficult to justify. Groundwater

9. Most ground and surface water contamination unrelated to waste disposal derives from nonpoint sources. Nonpoint sources of such contamination include mine drainage, saltwater intrusion, and runoff or seepage from agriculture, silviculture, urban development, and construction sites. See Conservation Foundation, supra note 7, at 123-28.

10. 33 U.S.C. $\S \S 1251-1376$ (1982).

11. "Point source" is defined supra note 6. CWA declares that "the discharge of any pollutant by any person" is unlawful unless explicitly permitted. 33 U.S.C. $\S 1311$ (a) (1982). This broad prohibitory language is in fact directed only at point source discharges made directly into navigable surface waters. Id. § 1362(12). See also Kelley v. United States, No. G83-630 (W.D. Mich. Sept. 20, 1985) (CWA does not apply to discharges into groundwater, even if they eventually migrate into surface waters); DiNovo \& Jaffe, Local Regulations for Groundwater Protection Part I: Sensitive-Area Controls, LAND Use L. \& Zoning Dig., May 1984, at 6, 7 (EPA does not apply CWA to groundwater). A variety of other federal statutes provide some protection for groundwater in a piecemeal fashion. See United States Environmental Protection Agency, Ground-Water ProtecTION StRategy 31 (1984) [hereinafter cited as Ground-WATER Strategy]. The Safe Drinking Water Act Amendments of 1986 establish a program for state protection of areas surrounding wells which supply public water systems. The program is essentially voluntary because enforcement is limited to EPA denial of funding for the program's implementation. The Safe Drinking Water Act Amendments of 1986, Pub. L. No. 99-339 (signed into law June 19, 1986, Statement on Signing $S$. 124 Into Law, 22 Weekly Comp. Pres. Doc. 831 (1986)).

12. 33 U.S.C. $\$ \S 1311-1345$ (1982). Eflluent standards are uniform standards applied to the quality of waste discharges into receiving waters. Ambient standards regulate the quality of receiving waters. Pollutant sources are identified and regulated to the extent necessary to maintain the ambient standards.

13. Id. $\$ 1288$.

14. Id. § $1288(\mathrm{~b})(2)(\mathrm{F})-(\mathrm{K})$.

15. See id. $\S \S 1285(\mathrm{~g}), 1285(\mathrm{j}) ; 40$ G.F.R. $\S \S 35.300,35.350$ (1985).

16. 33 U.S.C. $\$ 1313(\mathrm{e})(1982)$. See Goldfarb, Water Quality Management Planning: The Fate of 208, 8 U. Tol. L. REv. 105, 123 (1976) (questioning effectiveness of this sanction); see also D. Mandelker, Environmental and Land Controls Legislation 54 (Supp. 1978) ("there appears to be no unalloyed obligation to adopt a 208 plan once it is prepared"). 
provides drinking water to over half of the American population, ${ }^{17}$ feeds and is fed by surface water, ${ }^{18}$ and once contaminated is virtually impossible to clean. ${ }^{19}$ Nonpoint source pollutants (whether or not related to waste disposal) can be as dangerous as point source discharges, ${ }^{20}$ and can render successful point source control a nullity. ${ }^{21}$ Groundwater and nonpoint source pollution now threaten to completely overshadow the problem of point source pollution of surface waters. ${ }^{22}$

The regulatory differential can be attributed in significant part to the need to regulate land use in order to control groundwater and nonpoint source pollution. Land use regulation is widely considered a local prerogative. ${ }^{23}$ Thus, state legislatures and Congress have been reluctant to include such regulation in their water pollution legislation.

\section{B. The Need for Land Use Regulation}

Groundwater and nonpoint source pollution are difficult, and often impossible, to regulate by the traditional methods used to regulate point source discharges into surface water: effluent and ambient standards. ${ }^{24}$ Ef-

17. Ground-Water Strategy, supra note 11 , at 11 .

18. V. Pye, R. PATrick \& J. Quarles, supra note 3, at 4. Because ground and surface waters are interconnected, "[p]rotection of one . . . is meaningless without concomitant measures to protect the other." Note, Section 1424(e) of the Safe Drinking Water Act: An Effective Measure Against Groundwater Pollution?, 6 EnvTL. L. ReP. (ENVTL. L. INST.) 50121, 50121 (1976).

19. V. Pye, R. Patrick \& J. Quarles, supta note 3, at 269.

20. See E. Laws, AQUatic Pollution 90 (1981) (agricultural and urban runoff); V. Novotny

\& G. Chesters, supra note 7, at 2,11,314; L. Ortolano, supra note 8, at 397.

21.

[I]t has been estimated that perhaps $80 \%$ of the urban areas in the United States will not realize increased water quality from extensive treatment of point sources. . . . Recent evidence indicates that pollution inputs from nonpoint sources in the form of stormwater runoff or drainage due to routine land use practices is responsible for a large part of the degradation of surface water quality.

T. Watte, Principles of Water QualtTy 255-56 (1984) (emphasis in original).

22. The Conservation Foundation concludes that "[w]hile the quality of surface water may be at least holding its own, groundwater quality may be deteriorating." CoNSERvaTION Foundarion, supra note 7 , at $x \times v$. In addition, one of "the most important reasons for the lack of progress in controlling many water pollutants [is] that: very little effort has been made to control nonpoint sources ...."Id. See also V. Novotny \& G. CHesters, supra note 7, at 2 ("Nonpoint sources of pollution account for more than $50 \%$ of the total water quality problem . . . ."); Getches, Controlling Groundwater Use and Quality: A Fragmented System, 17 NAT. Resources LAW. 623, 631 (1985) (groundwater pollution poses "graver threat" than surface water pollution).

23. See L. Ortolano, supra note 8, at 216; Michelman, Localism and Political Freedom, in The Land Use Policy Debate in the United States 239 (J. de Neufville ed. 1981).

24. Effluent standards may not protect groundwater from point source contamination because it is extremely difficult to determine how a particular discharge will affect water quality. See ENvironMENTAL. LAW INSTITUTE, supra note 3, at 663. Because of their dispersed nature, nonpoint pollutants cannot be regulated by effluent standards. Pisano, Nonpoint Pollution: An EPA View of Areawide Water Quality Management, 31 J. Soll \& WATER Conservation 94, 95-96 (1976).

Ambient standards are difficult to maintain because it is often impossible to trace the cause of a violation, especially, as is common with nonpoint pollution, if there are many nearby sources of the pollutant. See L. ORTolano, supra note 8, at 116 . The hidden nature of groundwater may make significant ambient monitoring impossible. See Ground-Water Strategy, supra note 11, at 16. 
fective regulation must include broader controls aimed directly at pollution-causing land uses, ${ }^{25}$ particularly when pollution is caused by activities unrelated to waste disposal. ${ }^{28}$ Most types of development, whether urban/industrial, ${ }^{27}$ suburban/residential, ${ }^{28}$ or rural/agricultural, ${ }^{29}$ can contribute to groundwater and nonpoint source pollution. Land use regulations which can prevent such pollution fall into two categories. Land use controls, which regulate the location of land uses, may, for example, prohibit certain types ${ }^{30}$ or densities ${ }^{31}$ of land use. In addition, land manage-

25. See ENVIRONMENTAL LAw INSTTTUTE, supra note 3, at 663 (groundwater); V. NovotNy \& G. Chesters, supra note 7, at 391-433, 439-58 (nonpoint pollution); V. Pye, R. PATRICK \& J. QUARLES, supra note 3, at 268-69 (groundwater); Goldfarb, supra note 16, at 107 (nonpoint pollution); Miller, Protection of Groundwater Quality, in Groundwater Pollution: ENvironmental. AND Legal Problems 93, 123, 128-29 (C. Travis \& E. Etnier eds. 1984) (groundwater/nonpoint pollution); Stephenson \& Lemmon, Land Use Controls to Protect Groundwater Quality in the Arid Southwest, 5 EnvTl. Prof. 98 (1983) (groundwater); Tarlock, supra note 1, at 122 ("Since groundwater contamination is largely a function of what land uses are allowed over an aquifer, local governments have begun to expand their land use controls to include aquifer protection strategies."); Tripp \& Jaffe, supra note 5, at 34 (land use controls are necessary to protect groundwater because "the technology for controlling groundwater pollution from waste facilities is simply not adequate to assure non-degradation," and "no technology can control the nonpoint source contamination inevitably resulting from intensive residential, commercial, and industrial development").

26. See V. Pye, R. PATrick \& J. QuArles, supra note 3, at 261-62 (pollutants from sources unrelated to waste disposal "are so diffuse that they cannot ordinarily be reached by direct regulation, but only indirectly through restrictions on the activities that generate them").

27. See City of Austin v. Jamail, 662 S.W.2d 779, 782 (Tex. Ct. App. 1983) (nonpoint pollution); V. Novotny \& G. Chesters, supra note 7, at 7-9, 312-45 (same); see also T. WAITE, supra note 21 , at 256 (urban runoff "contains organic wastes, bacterial contaminants, metals, suspended solids, and other pollutants"); Stephenson \& Lemmon, supra note 25, at 101, 104 (industrial development may cause contamination of groundwater by toxic chemicals).

28. See In re Spring Valley Development, 300 A.2d 736, 740 n.2 (Me. 1973) (groundwater/ nonpoint pollution); Southern Burlington County NAACP v. Township of Mount Laurel (Mount Laurel II), 92 N.J. 158, 311-12, 456 A.2d 390, 469 (1983) (same); see also V. NovotNy \& G. Chesters, supra note 7, at 393, 407 (groundwater/nonpoint pollution from residential development includes discharges from septic tanks, erosion, and wash-off of street dust and curb refuse).

29. See Conservation Foundation, supra note 7, at 123-25 (agricultural lands are greatest source of nonpoint pollution, "contributing most of the sediment, nitrogen, phosphorus, and [biochemical oxygen demand] entering U.S. surface waters"); P. KRENKEL \& V. NovotNy, WATER QUALITY MANAGEMENT 219-35 (1980) (nonpoint pollution caused by rural/agricultural land use).

30. In certain circumstances, development must be prohibited altogether. For example, to protect groundwater, development may be banned in the area surrounding a well. See DiNovo \& Jaffe, supra note 11, at 10-11. To prevent nonpoint pollution of surface waters, development may be banned on the land immediately surrounding a watercourse. See id. at 12.

Or, land use controls may focus more narrowly on restricting specific sources of harmful pollutants, such as waste landfills, commercial enterprises that store or use hazardous materials, housing developments that utilize septic tanks, commercial development in sensitive areas, or land uses that contribute significantly to erosion. See DiNovo \& Jaffe, Local Regulations for Groundwater Protection Part II: Source Controls, LAND Use L. \& Zoning Dig., June 1984, at 5, 5-8; DiNovo \& Jaffe, supra note 11, at 11-13; Harrington, Krupnick \& Peskin, Policies for Nonpoint-source Water Pollution Control, $40 \mathrm{~J}$. SOIL \& WATER CONSERvation 27, 29 (1985); Stephenson \& Lemmon, supra note 25, at 101, 103-04.

Another regulatory approach that tends to be more closely tailored to the impact of an activity on water quality is the performance standard. Performance standards do not restrict specified land uses, but rather restrict only those land uses that cause a particular adverse effect, such as sediment pollution. See Harrington, Krupnick \& Peskin, supra, at 29.

31. See Ground-Water STrategy, supra note 11, at 23 (limitations on density of commercial 
ment regulations often must be prescribed to prevent pollution from land uses not prohibited by location controls. ${ }^{32}$

\section{The Inadequacy of Existing Regulation}

The EPA has very limited authority to regulate land uses $^{\mathbf{3 3}}$ that threaten groundwater quality ${ }^{34}$ and/or cause nonpoint pollution..$^{35}$ Moreover, CWA has done little to encourage state regulation of such land uses. When enacted, section 208 was considered the "most important aspect of a water pollution control strategy" largely because of its land planning provisions. ${ }^{36}$ Congress recognized that "[u]ncontrolled growth and expansion and competition among units of government will be reduced if effective environmental controls are to be imposed." neither procedural nor substantive requirements designed to enhance state control over land uses that cause groundwater or nonpoint source pollution. ${ }^{38}$

or residential development over aquifer recharge areas); V. PYE, R. PATRICK \& J. QUARLES, supra note 3, at 268 (same); V. NovotNy \& G. Chesters, supra note 7, at 440 (use of density regulation to control nonpoint pollution).

32. See Federman, The 1972 Water Pollution Control Act: Unforeseen Implications for Land Use Planning, 8 URB. LAw. 140, 143 (1976) (nonpoint pollution); Tarlock, supra note 1, at 126 (groundwater).

33. This Note excludes from the term "land use regulation" controls on the operation (as opposed to the siting) of waste disposal facilities. The EPA has authority to regulate waste disposal facility operation under the Resource Conservation and Recovery Act, 42 U.S.C.A. $\$ \S 6901-6991$ i (West 1983 \& Supp. 1986).

34. The EPA has direct control over land uses which threaten groundwater only under section 1424(e) of the Safe Drinking Water Act. 42 U.S.C. $\$ 300 \mathrm{~h}-3$ (e) (1982). This provision enables the EPA to withhold federal grants or contracts from any project that threatens to contaminate an aquifer designated as the sole or principal source of drinking water for a region, if such contamination would create a significant hazard to public health. Although a useful regulatory tool, section 1424(e) has not been effectively employed. Tripp, Groundwater Protection Strategies: Federal, State and Local Relationships, in Groundwater Pollution: Environmental and Legal Problems 131, 146 (C. Travis \& E. Etnier eds. 1984). In addition, its value is greatly limited because it is not incorporated into a land planning program, and therefore cannot take cumulative development effects into account. See Note, supra note 18, at 50125-26.

35. See Council on Environmental Quality, Environmental Quality 1981, at 83 (1981) (GWA "gives EPA no specific authority to regulate pollution from nonpoint sources"). But see 33 U.S.C. $\$ \S 1288(\mathrm{~b})(4)(B)-(C), 1344$ (1982) (establishing federal authority to control nonpoint pollution from dredging and filling activities in wetlands if state does not develop adequate program for control of such pollution); id. $\$ 1314$ (e) (granting EPA authority under very limited circumstances to regulate land management practices in order to control industrial nonpoint pollution).

36. See 1 Senate Comm. on Public Works, 93D Cong., 1st Sess., A Legislative History of the Water Pollution Control Act Amendments of 1972, at 782 (Comm. Print 1973).

37. S. Rep. No. 414, 92d Cong., 2d Sess., reprinted in 1972 U.S. Cone Cong. \& AD. NewS $3668,3704$.

38. Section 208 merely suggests that "land use requirements" be one of the methods utilized to control nonpoint pollution. 33 U.S.C. $\$ 1288(\mathrm{~b})(2)(\mathrm{F})-(\mathbf{H})(1982)$. Moreover, it provides for regional rather than state supervision of areas with "substantial water quality control problems." Id. § 1288(a)(2). 
Although a few states have developed land use programs for land overlying particularly sensitive and valuable aquifers, ${ }^{30}$ no state has implemented a statewide program directed at protecting groundwater. ${ }^{40}$ Instead, the states have relied upon local governments to protect groundwater through zoning and public health regulations. ${ }^{41}$ Similarly, responsibility for regulating nonpoint source pollution lies largely at the local level. ${ }^{42}$ Most local programs are voluntary. ${ }^{43}$

In short, though acknowledging the value of land use regulation in protecting the environment, section 208 leaves states free to determine whether they will utilize such regulation to control groundwater and nonpoint source pollution. The states in turn have largely delegated responsibility for these problems to local governments. Yet relying on local governments to voluntarily use land use regulation to control groundwater and nonpoint source pollution makes little more sense than relying on industrial and municipal point source dischargers to regulate themselves. As with self-regulation by the latter, self-regulation by the former imposes substantial external costs.

\section{UNDERREGULATION}

Since the 1970's, a number of states have developed legislation providing for some form of state control over land use. ${ }^{44}$ Most of this legislation has been prompted by the failure of local governments adequately to regulate the adverse environmental consequences of development. ${ }^{15}$ Absent state regulation, local governments are able to encourage or tolerate harm-

39. Two of the most extensive such programs have been developed by New Jersey (Pine Barrens) and Texas (Edwards Aquifer). See Tripp \& Jaffe, supra note 5, at 38-42.

40. See V. Pye, R. PAtrick \& J. QuArLes, supra note 3, at 269 ("Land-use controls have . . not yet been applied in any state except in reference to special, localized situations."); $c f$. GrounDWATER STRaTEGy, supra note 11, at 22 ("Several States have the authority to impose some type of State land-use controls, but only a few actively use them to protect ground water.").

41. DiNovo \& Jaffe, supra note 11, at 7. Even groundwater-conscious states such as Connecticut and Florida have largely delegated regulatory responsibilities to local governments by merely authorizing them to use zoning powers to protect aquifers. See V. PyE, R. PATRIck \& J. QuARLEs, supra note 3 , at 275,277 . This approach is not always ineffective. For example, Southington, Connecticut, has incorporated an extensive groundwater protection program into its zoning ordinance. See DiNovo \& Jaffe, supra note 11, at 11-12.

42. See Environmental Law Instrtute, supra note 3, at 517; V. Novotny \& G. CheSters, supra note 7, at 19-20; Massey, Land Use Regulatory Power of Conservation Districts in the Midwestern States for Controlling Nonpoint Source Pollutants, 33 DRAKE L. REV. 35, 36-37 (1983-84). This local emphasis continues even though in the 1970's the EPA concluded that, due to "potential political impediments and the lack of available sanctions," state rather than local governments would have to be largely responsible for implementing nonpoint source regulations. Goldfarb, supra note 16, at 129.

43. See Council. on Environmentaz Quality, supta note 35, at 83; Environmental. Law INSTITUTE, supra note 3, at 523.

44. See generally R. Healy \& J. Rosenberg, Land Use and the States (2d ed. 1979) (describing state programs).

45. See id. at 1; J. Kusler, Regulating Sensitive Lands at vii (1980). 
ful land uses without considering the consequences which extend beyond local boundaries. Because underregulation of harmful land uses results from defects in the local land use decisionmaking process, many states have found that the process itself is an appropriate object of regulation. A process-oriented approach that requires local governments to develop land use programs to control groundwater and nonpoint source pollution, and enables states to correct the programs' inadequacies, can ensure that local governments consider regional and state water quality interests. ${ }^{46}$

\section{A. Environmental Spillovers}

A community may tolerate pollution-causing land uses because of a desire to attract development, or a reluctance to regulate politically influential land users. ${ }^{47}$ But another important cause of inadequate land use regulation is simply the financial, technical, or legal inability of many local governments to investigate environmental problems and design effective cures. ${ }^{48}$ As a result, local land use controls commonly operate to promote local economic development at the expense of the environment. ${ }^{49}$

To the extent that they do take steps to protect the environment through the regulation of land use, local authorities tend to focus on amenity values (e.g., aesthetics, recreation, open spaces, clean-looking lakes or streams, elimination of obvious pollutant sources) rather than on technically oriented public health needs. ${ }^{30}$ The effects of regulations which protect local amenities are more readily observable, and thus such regulations may be more politically acceptable. ${ }^{51}$ As a result, groundwater and

46. Because local governments acquire their authority to regulate land use from the states, the states are in the best position to remove the authority that allows local land use decisions to adversely affect regional or state interests. See Delogu, Local Land Use Controls: An Idea Whose Time Has Passed, 36 ME. L. REv. 261, 297-98 \& n.102 (1984). Because state interests are involved, home rule is not a significant legal obstacle. See Developments in the Law-Zoning, 91 Harv. L. REv. 1427, 1619 (1978) [hereinafter cited as Developments].

Reliance on regional agencies is not a viable alternative. Generally controlled by local authorities, and lacking a distinct political constituency, regional organizations are likely to be as unwilling and unable to control harmful land use practices as local governments. See Godschalk \& Brower, Beyond the City Limits: Regional Equity as an Emerging Issue, 15 URB. L. ANN. 159, 196-98 (1978); Developments, supra, at 1591-92.

47. See Developments, supra note 46 , at 1590 .

48. See R. Healy \& J. Rosenberg, supra note 44, at 189 ("Local governments may find it difficult . . . to impose conditions on projects which are built on land already zoned to that use . . . ."); Developments, supra note 46, at 1591 (localities "frequently lack the personnel and expertise necessary to handle the complexities of environmental land use planning") (footnote omitted).

49. See Developments, supra note 46 , at 1590.

50. Cf. C. Miller \& C. Wood, Planning and Pollutution 108 (1983) (discussing concerns of local authorities in U.K.). This may in part explain why "[t]he growth of scientific knowledge pertinent to land use policy has not yet been adequately accommodated in the law." Caldwell, Law and Land: The Ecology and Sociology of Land Use Planning, in LAND IN AMERICA 187, 205 (R. Andrews ed. 1979). Caldwell cites policies to protect aquifers and groundwater as two key examples of policies which "often run against the grain of the law." Id.

51. See V. Novotny \& G. Chesters, supra note 7, at 488 ("The priorities in . . a llocal 
nonpoint source pollution control may suffer-efforts to regulate such pollution often do little to preserve amenity values.

These flaws in the local land use decisionmaking process become a matter of state concern in the event of intermunicipal pollutant spillover from land uses which cause groundwater or nonpoint source pollution. Even if a locality is aware of groundwater or nonpoint source pollution problems, it has little incentive to control them if the costs are borne primarily by residents outside the host community. State supervision of local land use regulation can provide the requisite regional perspective.

\section{B. Economic Spillovers}

State review of local land use regulations need not rely on environmental spillovers as its sole justification. Communities with comparatively weak environmental regulations-"pollution havens"-may cause regional economic harm not directly related to any accompanying environmental damage.

Compared to most forms of pollution control, which are generally subject to state and federal supervision, local land use regulations are easily modified and thus particularly susceptible to erosion. ${ }^{52}$ The reliance of groundwater and nonpoint source pollution control on land use regulation thus makes such control particularly susceptible to the "pollution haven" problem. Intentionally or unintentionally, pollution havens may attract desirable development from communities with stricter environmental programs, thereby imposing costs on those communities. Localities with strict regulatory programs suffer economic harm even without actual migration of development if pollution control costs discourage economic growth ${ }^{63}$ or create price differentials which have an adverse effect on demand for local products. ${ }^{\text {. }}$ These adverse economic spillovers caused by pollution havens justify uniform state pollution control standards regardless of the level of intermunicipal environmental spillover. ${ }^{\text {s5 }}$ The fact that economic spillovers are caused by defective public rather than private land use decisions

water quality management] process may frequently be related to the "visibility' of the pollution input and its consequences.").

52. See L. Ortolano, supra note 8, at 216; Delogu, supra note 46, at 295-96; Shapiro, The Zoning Variance Power-Constructive in Theory, Destructive in Practice, 29 MD. L. REv. 3 (1969).

53. See Stewart, Pyramids of Sacrifice? Problems of Federalism in Mandating State Implementation of National Environmental Policy, 86 YALE L.J. 1196, 1216 (1977).

54. Cf. Heady \& Nagadevara, Economic Impacts of State Environmental Programs in a National Framework: The Iowa Conservancy Law, 30 J. Soll \& WATER ConSERvation 272, 272, 278 (1975) (environmental restraints on agriculture, if implemented solely in Iowa, would reduce farm income in state and increase farm income elsewhere in nation).

55. See Stewart, supra note 53, at 1215-16 (both environmental and economic spillovers can justify centralized regulation). 
provides an additional justification for state regulation of the local land use decisionmaking process.

\section{G. A Legislative Approach for State Control of Local Underregulation}

In recognition of the defects in the local land use decisionmaking process, state land use regulation often focuses on the process rather than on the direct cause of environmental harm-the land user. Under a prominent form of regulation, the state develops guidelines, requires local governments to prepare corresponding plans, and reviews local land use regulations or development permits to ensure that they are consistent with the guidelines. ${ }^{56}$ This approach is in essence conscriptive: Local governments are ordered to shoulder the initial burden of developing and enforcing state land use requirements. After reviewing local efforts for compliance with state guidelines, the state may modify or replace inconsistent local regulations, ${ }^{57}$ order their amendment by the local government, ${ }^{58}$ appeal

56. See J. KusLeR, supra note 45 , at 8. See generally id. at 175-84 (comprehensive list of state land use programs).

57. See FlA. Stat. ANN. $\$ 380.05$ (8) (Harrison Supp. 1984) (if local governments fail to submit adequate land development regulations for critical areas, state may develop provisions to supplement or supersede local regulations); ME. REv. STAT. ANN. tit. 38, § 442 (Supp. 1985) (if municipal shoreland regulation is inadequate, state shall adopt suitable ordinances, which municipality must then administer and enforce); MinN. STAT. ANN. § 116G.09(1) (West Supp. 1986) (if local government fails to prepare adequate critical area plans, state will adopt such plans, which "shall apply and be effective as if adopted by the local unit of government"); WASH. REv. CODE ANN. $§ 90.58 .070(2)$ (Supp. 1986) (if local government fails to adopt master program for shorelines within its jurisdiction, state will do so); see also MODEL LAND DEv. CoDE § 7-204 (1976) (state may develop critical area regulations if local effort is inadequate; state-developed regulations will be administered locally as if they were part of local development ordinance).

An analogous approach involves the application of pre-established state guidelines and/or enforcement measures in the absence of adequate local programs. Once adequate programs are developed, the validity of proposed land uses is evaluated locally on the basis of conformity with local regulations. See, e.g., Gal. Pub. Res. Code $\S \S 30519$ (a), 30600.5, 30604(a)-(b) (West Supp. 1986) (coastal zone). A number of states have used this approach in order to control certain forms of nonpoint pollution. For example, under the New Jersey Soil Erosion and Sediment Control Act, N.J. STAT. ANN. $\S \S 4: 24-39$ to -55 (West Supp. 1985), developments must acquire certification by a local Soil Gonservation District of a plan for soil erosion and sediment control before the development application may be approved by a municipality. Id. $\S 4: 24-43$. Municipalities which adopt ordinances conforming to standards promulgated under the Act, however, are exempt from this requirement. Id. § 4:24-48. See also GA. CODE ANN. § 12-5-444(a)-(b) (Supp. 1985) (stating broadly that development in certain stream corridors that inter alia causes nonpoint pollution is unlawful; once area land and water use plans are adopted, lawfulness will be judged by reference to area plans); MD. NAT. RES. CODE ANN. § 8-1103 (Supp. 1985) (municipalities may request delegation of enforcement responsibilities for state sediment control requirements; state will enforce requirements if municipality is unable or unwilling to do so); N.C. GEN. STAT. §§ 113A-54, 113A-60 (1983) (state has general regulatory authority over erosion and sedimentation; local governments have option to submit erosion and sediment control program to state for approval).

58. See Cal. Pub. Res. Code $\S \S 30512(b), 30513$ (West Supp. 1986); OR. Rev. Stat. § 197.320(1) (1985); cf. ME. Rev. Stat. ANN. tit. 38, $\S 443$ (Supp. 1985) (municipal officers in noncompliant communities subject to suit by Attorney General requiring them to enforce state land use requirements). Maryland uses this approach to control stormwater runoff. See MD. NAT. RES. CODE ANN. § 8-11A-06(d) (1983). 
undesirable land use decisions to an adjudicatory board, ${ }^{59}$ or penalize local governments with inadequate regulatory programs. ${ }^{60}$ Existing state review programs, however, are almost invariably limited to small, environmentally critical portions of the state. ${ }^{61}$

A federal program for groundwater and nonpoint source pollution control should focus on promoting state authority to review and influence local regulations instead of requiring direct state regulation of land users. Such an approach is both an effective method of controlling water pollution and a means of according due attention to local and state interests.

\section{Practical Value of State Review of Local Regulations}

Environmental harm commonly occurs only as the result of an accumulation of land uses which are in themselves harmless. ${ }^{62}$ Thus, absent some conception of the course of development within a community, it may be impossible to designate a particular land use as environmentally harmful. ${ }^{\text {e3 }}$ Developers often cannot be expected to predict the cumulative impact of development, and generally have little control over the course of development in a locality. Ultimate responsibility for prediction and control of the cumulative impacts of development should therefore be placed on government. ${ }^{84}$ Where the course of development threatens water qual-

59. See Cal. Pub. Res. Code $\S 30625$ (a) (West Supp. 1986); Fla. Stat. AnN. $\S 380.07(2)$ (Harrison Supp. 1984); Wash. Rev. Code ANN. $\$ 90.58 .180(2)$ (Supp. 1986).

60. One common form of penalty is the withholding of state or federal funding. See Southern Burlington County NAACP v. Township of Mount Laurel (Mount Laurel II), 92 N.J. 158, 234-35, 456 A.2d 390, 429 (1983) (funding decisions based on local compliance with New Jersey State Development Guide Plan); OR. Rev. STAT. § 197.320(5) (1985) (grant withholding used to enforce state land use requirements). Another type of penalty entails placing substantial limits on the issuance of local development permits until adequate regulations are adopted. See OR. REv. STAT. $\$ 197.320(4)$ (1985); cf. Mich. Comp. LAws ANN. \$281.640 (West 1979) (under shorelands protection program, inadequate local zoning ordinances shall have no "force or effect" until approved by state). Maryland used the threat of a building permit ban to force local governments to adopt stormwater runoff control ordinances. Benner, Urban Sediment and Stormwater Control: The Maryland Experience, $40 \mathrm{~J}$. SOIL \& WATER Conservation 72, 75 (1985).

61. Some state courts, relying on common law and general state zoning enabling and environmental policy acts, have imposed statewide controls on the adverse regional environmental consequences of local land use regulation. These courts have held that localities must give reasonable consideration to regional environmental welfare when making land use decisions. See Committee for Sensible Land Use v. Garfield Township, 124 Mich. App. 559, 567-70, 335 N.W.2d 216, 220-21 (1983); Save A Valuable Env't v. City of Bothell, 89 Wash. 2d 862, 870-72, 576 P.2d 401, 406-07 (1978). See generally Village of Euclid v. Ambler Realty Co., 272 U.S. 365, 390 (1926) (a municipality may not "stand in the way ... where the general public interest . . . far outweigh[s] the interest of the municipality"). Court-imposed restraints are of limited value, however, because substantive land use guidelines will generally not be imposed absent specific legislative direction.

62. See R. HeAly \& J. Rosenberg, supra note 44, at 22 (also noting that cumulative damage may be far harder to remedy than damage from isolated conspicuous sources); Pisano, supra note 24, at 96 (nonpoint pollution usually results from "consecutive operations on extensive units of land").

63. See R. HeAly \& J. ROSENBERG, supra note 44 , at 235.

64. Cumulative impact review means that "the incremental effects of an individual project [are] reviewed in connection with the effect of past projects, the effects of other current projects, and the effects of probable future projects." CaL. PUB. REs. Code $\S 30105.5$ (West Supp. 1986). 
ity, the local land use regulations which in large part guide development are a natural object of state regulation. ${ }^{65}$

By encouraging or tolerating an environmentally harmful course of development, a local government is in a very real sense a cause of the harm. The wide use of conscriptive state land use programs indicates that many states have acknowledged local government responsibility for harmful land use practices. As a corollary to this responsibility, localities can in certain circumstances be expected to subsidize (with assistance from state and federal government) the cost of groundwater and nonpoint source pollution control. ${ }^{88}$ Emphasis on local responsibility for pollution-causing land uses also provides a justification for directing enforcement efforts at local governments rather than at land users. ${ }^{87}$

\section{Local and State Interests}

Regulation of the local regulatory effort, rather than of land users, also accords due attention to competing values of purely local impact. When developing a regulatory program pursuant to state guidelines, communities can accommodate a variety of local interests. ${ }^{88}$ Upon review, the state can analyze the impact of local plans on groundwater and nonpoint source pollution and determine whether the local effort unnecessarily compromises regional interests.

In addition, state review of local plans is less burdensome on the state than the two primary alternative methods of state land use control: direct land use regulation of critical areas and direct review of all major developments. The former approach replaces local land use authority; the latter duplicates it. As a practical matter, it is easier to regulate local regulations than it is to regulate the myriad land uses that contribute to pollution. ${ }^{\text {g9 }}$

65. See Developments, supra note 46 , at 1601 . Under the California coastal program, for example, researchers have evaluated the potential cumulative effects of local land use plans on both the quantity and quality of local water supplies. See Comment, An Expanded Role for the State in Regional Land Use Control, 70 CALIF. L. REv. 151, 166-69 (1982).

66. Cf. Westwood Forest Estates, Inc. v. Village of S. Nyack, 23 N.Y.2d 424, 427, 244 N.E.2d $700,702,297$ N.Y.S.2d 129, 132 (1969) (local land use regulation may not "single out [a landowner] to bear a heavy financial burden because of a general condition in the community") (citations omitted). Such subsidies may be direct or indirect. For example, direct subsidization of farmers is widely considered to be a prerequisite to control of agricultural nonpoint pollution. Harrington, Krupnick \& Peskin, supra note 30 , at 31 . Indirect subsidization may for example consist of government condemnation of a buffer zone between a sensitive watercourse and urban development.

67. See infra text accompanying notes 70-73.

68. Cf. Gity of Austin v. Jamail, 662 S.W.2d 779, 782 (Tex. Ct. App. 1983) ("Local governments are in a better position to address the problem of urban runoff for they are most familiar with local growth patterns, local terrain, and their master plans of development.").

69. Nevertheless, direct state regulation may be desirable for very sensitive areas or particularly dangerous pollution sources if local governments cannot develop the requisite regulatory resources. 


\section{Enforcement}

Enforcement of state land use guidelines designed to control groundwater and nonpoint source pollution can be undertaken by both state and local agencies, and by the courts. No single method of state enforcement can be applied to all states and to all types of pollution problems..$^{70}$ Ideally, regulatory programs should use the threat of state-developed measures as an enforcement tool. In addition, local governments can justifiably be penalized if they fail adequately to regulate land users. Once pollutioncausing land uses are allowed to proceed, it may be unfair ${ }^{71}$ or economically infeasible to terminate them. The only remedies may be prospective: for example, prohibiting, or removing state and federal financial support for, further development desired by the community. ${ }^{22}$

Reliance solely on withholding government funding from noncompliant localities is a barely adequate alternative, but may be the only politically acceptable approach for at least some parts of the regulatory program. Enforcement by the courts will be of particular value for programs that rely largely on grant withholding. Even if state guidelines are not formally enacted as law, courts can utilize them to determine whether an environmentally harmful local land use decision is invalid because it harms the regional welfare. ${ }^{73}$

\section{Overregulation}

Any land use program must attend to spillovers caused by overregulation in addition to those caused by underregulation. ${ }^{74}$ Overregulation occurs when excessive local restrictions operate to exclude from a community land uses which, from a regional standpoint, should be allowed to take place in that community. ${ }^{75}$ Growing environmental concern has

70. For examples of state enforcement approaches, see supra notes 57-60 and accompanying text.

71. Termination may be unfair if the land user reasonably relied upon a government prediction that the land use would not compromise water quality goals.

72. In contrast, the comparative discreteness, obviousness, and reversibility of point source discharges into surface waters generally make it more practicable and justifiable to penalize individual polluters rather than inadequate regulators of those polluters.

73. See supra note 61 .

74. Local land use controls have been heavily criticized for being unfairly or unnecessarily restrictive in a variety of contexts. See, e.g., PResident's Commission on Housing, The RePort of the President's Commission on Housing 200-02 (1982) (advocating heightened scrutiny of zoning regulations which limit development of housing); Delogu, supra note 46 (local land use control should be replaced by state/regional control); Ellickson, Alternatives to Zoning: Covenants, Nuisance Rules, and Fines as Land Use Controls, 40 U. CHI. L. REv. 681 (1973) (zoning should be replaced by system of private adjustments implemented through lawsuits); Krasnowiecki, Abolish Zoning, 31 SyRACUSE L. REv. 719, 748 (1980) (acceptances and rejections of requests for zoning changes should be treated as administrative adjudications rather than legislative actions). This Part seeks to describe only a few of the circumstances where reduction of local power over land use is appropriate.

75. Cf. Delogu, The Misuse of Land Use Control Powers Must End: Suggestions for Legislative and Judicial Responses, 32 ME. L. REv. 29, 76 (1980) (Land use "[c]ontrols which significantly . . . 
brought increased pressure on local governments to exclude purportedly harmful land uses and increased efforts by the states to prevent exclusions that cause harm extending beyond local boundaries.

Because many types of land use have the potential to cause groundwater or nonpoint source pollution, ${ }^{78}$ increased attention to such pollution may result in excessive local land use restrictions that harm regional interests, ${ }^{77}$ and excessive judicial deference to such restrictions. At a particular site, a variety of regulatory approaches, some more restrictive and some less restrictive of development which is desirable from a regional standpoint, may be adequate to control groundwater ${ }^{78}$ and nonpoint ${ }^{79}$ pollution problems. Where more restrictive approaches cause adverse spillovers, less restrictive approaches should be encouraged or required. Also, within a particular region, land use in some areas may pose a greater threat to water quality than land use in other areas. ${ }^{80}$ It may therefore be in the regional interest to channel certain land uses from less safe areas to more safe areas by removing excessive restrictions on those land uses in the safer areas. ${ }^{81}$

As with underregulation, the costs of overregulation are due in large part to defects in local land use decisionmaking processes. Thus, the states

preclude otherwise legal and in many cases socially necessary undertakings cannot be allowed to stand on the basis of generalized fears, overbroad assumptions, or unsubstantiated apprehensions about the existence of conditions which might give rise to harm.") (emphasis in original). My focus here is on restrictions which, despite benefitting the general welfare, must be eliminated because they also harm the general (regional) welfare. Judicial deference to land use regulations which, despite benefitting the general welfare, impose burdens on individual landowners has also been the subject of intense criticism. This Note nevertheless will assume that deference to the general welfare is appropriate.

76. See supra notes 27-29 and accompanying text.

77. See Associated Home Builders v. City of Livermore, 18 Gal. 3d 582, 589, 557 P.2d 473, 475-76, 135 Cal. Rptr. 41, 43-44 (1976) (noting "growing conflict between the efforts of suburban communities to check disorderly development, with its concomitant problems of air and water pollution and inadequate public facilities, and the increasing public need for adequate housing opportunities"); V. Novotny \& G. Chesters, supra note 7, at 393, 396 (indicating that use of land use regulation to control nonpoint pollution has potential to be simplistic and overbroad); Miller, supra note 25 , at 120 ("aquifer protection and growth are in many cases incompatible").

78. Regulations which focus narrowly on specific sources of pollution, or ambient water quality programs which establish pollutant limitations on a highly technical, case-by-case basis, see V. PYE, R. PATrick \& J. Quarles, supra note 3, at 261-68, may provide less restrictive alternatives to broadly sketched land use controls.

79. Less restrictive alternatives to the limitation of development that may cause nonpoint pollution include runoff collection or drainage systems. See V. NovotNy \& G. CHESTERS, supra note 7, at 459-84; DiNovo \& Jaffe, supra note 11, at 13. But see Graham v. Estuary Properties, Inc., 399 So. 2d 1374 (Fla.) (developer-proposed urban runoff drainage system would not eliminate nonpoint pollution risk; thus, state-imposed density restrictions on commercial development were justified), cert. denied sub nom. Taylor v. Graham, 454 U.S. 1083 (1981).

80. For example, land use over clean sections of aquifers will be less desirable than land use over already polluted sections. See Miller, supra note 25, at 123 (Long Island land use regulations designed to protect groundwater permit industrial activity over polluted zone).

81. For example, the New Jersey Pine Barrens management plan, which, inter alia, is designed to protect groundwater, directs growth to often unwilling communities in less sensitive areas within the Pine Barrens. See R. Babcock \& C. Siemon, The Zoning Game Revisited 145, 150 (1985). 
must regulate these processes. Attention to overregulation is of far greater importance when government is the focus of a regulatory program than when private actors are at issue: Government faces fewer incentives to act efficiently, particularly because it is generally insulated from competitive market pressures.

\section{A. Environmental Spillovers}

Local overregulation harms regional environmental interests when it excludes pollution-causing activities from comparatively safe sites and displaces them into less safe areas, or entirely excludes environmentally essential land uses from the region. ${ }^{82}$ Such overregulation causes health hazards and regulatory difficulties that would not have occurred had the safer sites been utilized. ${ }^{83}$ The effect is much like an environmental spillover caused by underregulation.

A community may intentionally overregulate because it is unwilling to deal with environmentally harmful land uses. Or, it may unintentionally overregulate because it does not have the technical or financial ability to tailor regulations to actual physical conditions. ${ }^{84}$ The resulting exclusions may be entirely legitimate from a local standpoint. ${ }^{85}$ It is only when regional environmental interests are taken into account that the restriction constitutes overregulation. Broad exclusionary restrictions must then be re-tailored by the state ${ }^{88}$ to correspond more reasonably to actual physical conditions. $^{87}$

In the context of pollution control programs, states usually preempt or

82. See In re Zoning Permit Application of Patch, 140 Vt. 158, 168-69, 437 A.2d 121, 126 (1981) (town may not require sanitary landfill permit seeker to show "absolutely that the project will not discharge toxic substances into the ground water" because that "would virtually preclude any landfills in the state, since contamination of ground water is always a possibility").

83. See R. Healy \& J. Rosenberg, supra note 44, at 183 ("environmental damage is done because the places most suited to the proposed project have rejected it locally").

84. See J. KuSLER, supra note 45, at 96 ("Local government units often apply rigid, prohibitory approaches" to sensitive area regulation due to insufficient technical or financial resources.); $c f$. Hopping \& Preston, The Water Quality Assurance Act of 1983-Florida's "Great Leap Forward" into Groundwater Protection and Hazardous Waste Management, 11 FLA. ST. U.L. REv. 599, 617 (1983) (Florida prohibits local governments from enacting hazardous waste facility regulations more stringent than those of state "[i]n recognition of the complexity and technical nature of most hazardous waste regulations").

85. A community blind to the adverse regional impact of overbroad restrictions may see no reason to incur the expense and effort needed to develop regulations more carefully tailored to existing physical conditions. Or, localities may intentionally choose to avoid all risk of pollution, however remote, despite the fact that alternative sites pose greater risks. See Tarlock, Siting New or Expanded Treatment, Storage, or Disposal Facilities: The Pigs in the Parlors of the 1980s, 17 Nat. Resources LAw. 429, 439 (1984).

86. See id. ("states have a comparative advantage over local governments in assembling and assessing the information needed to make risk-benefit safety judgments").

87. Cf. Warren County v. North Carolina, 528 F. Supp. 276, 289-90 (E.D.N.C. 1981) (local government may not frustrate state/federal PCB disposal program through total disposal ban designed to protect groundwater; thus, local regulations must reasonably reflect actual physical conditions). 
override overly restrictive local land use regulations in order to site especially dangerous (and therefore locally very undesirable) activities. Many states have imposed substantial limits on local land use controls in order to facilitate the siting of hazardous waste facilities-one of the most dangerous sources of groundwater and nonpoint pollution. ${ }^{88}$ The consideration accorded to local land use restrictions on hazardous waste facilities varies from state to state. Many state statutes preempt local restrictions that operate to exclude state-approved facilities. ${ }^{39}$ Other states provide for override of local restrictions only upon a special finding by the state. ${ }^{90}$ In either case, siting of hazardous waste facilities in violation of local restrictions is unlikely to occur unless it is necessary to meet an important state or regional need. The statutes differ primarily in the level of necessity which must be shown, and the formality with which necessity must be proven. ${ }^{91}$

Broader use of state invalidation of excessive local restrictions as part of a groundwater and nonpoint source pollution control program lacks one compelling justification of legislation focused narrowly on hazardous waste facility siting: the need to locate extremely dangerous activities at the most suitable sites. Nevertheless, all invalidations of excessive restrictions which cause environmental spillovers share a common justification: rejection of a purely local cost-benefit analysis. ${ }^{92}$ Cost-benefit assessments should instead be made from a regional perspective. This does not mean that a project site which leaves the region with a net benefit should auto-

88. See Conservation Foundation, supra note 7, at 66-85. For a detailed discussion of state treatment of local land use controls in the hazardous waste facility siting context, see Tarlock, supra note 85, at 438-48; Tarlock, Anywhere But Here: An Introduction to State Control of HazardousWaste Facility Location, 2 UCLA J. ENvTL. L. \& PoL'Y 1, 32-38 (1981).

89. See, e.g., GA. Code ANN. \$ 12-8-79 (1982); MD. NAt. Res. Code ANN. § 3-705(d) (1983); MinN. STAT. ANN. § 115A.28(2)-(3) (West Supp. 1986) (local restrictions preempted, but state will apply local requirements if reasonable and consistent with state requirements); N.J. STAT. ANN. § 13:1E-63 (West Supp. 1985); Ohio Rev. Code ANN. 3734.05(D)(3) (Page Supp. 1985); UtAh CoDE ANN. $\$ \S 26-14 a-5(2)(a), 26-14 a-8$ (1984) (despite preemption, state will take zoning classifications into account in making siting decisions).

90. See, e.g., Fla. Stat. ANN. § 403.723 (Harrison Supp. 1984) (applicant may appeal local denial; must clearly and convincingly establish that no significant adverse environmental or economic impact will ensue); ILL. ANN. STAT. ch. 111 1/2, $\$ 1040.1$ (a) (Smith-Hurd Supp. 1986) (applicant may appeal local denial to state board); PA. STAT. ANN. tit. 35, $\S 6018.504$ (Purdon Supp. 1985) (state may override local restrictions; justifications must be set forth in writing).

91. Energy facility siting has received similar treatment. In Montana, for example, the state energy facility siting board may override any local law or regulation if "as applied to the proposed facility, the law or regulation is unreasonably restrictive in view of the existing technology, of factors of cost or economics, or of the needs of consumers, whether located inside or outside of the directly affected government subdivisions." MONT. Code ANN. § 75-20-301(2)(f) (1985). See also Cal. PuB. RES. CODE $\S 25525$ (West 1977) (analogous provision regarding power facility siting). For a discussion of energy facility siting legislation, see Murray \& Seneker, Industrial Siting: Allocating the Burden of Pollution, 30 HAstrngs L.J. 301 (1978).

92. See C. MILlER \& C. WoOD, supra note 50, at 222 ("a planning authority cannot make a practice of simply rejecting [projects] which leave the local population ... with a net detriment and no means of compensation"). 
matically be accepted, whatever the local costs. Rather, it means that siting a land use in a particular locality should be required or encouraged despite a net local detriment if even greater detriments would result from the use of alternative sites within the region. ${ }^{93}$ Thus, if necessary to prevent diversion of development to less environmentally suitable sites, a community can justifiably be expected to tailor land use regulations to actual physical needs, and to make reasonable efforts to deal with their fair share of the pollution problems which inevitably accompany development.

In addition to hazardous waste facilities, other readily identifiable sources of groundwater or nonpoint pollution, such as nonhazardous waste landfills and industries which use hazardous chemicals, may be the most appropriate objects of a state tailoring requirement. Less discrete sources of groundwater or nonpoint pollution, such as general urban or residential development, may be less suitable for a tailoring requirement unless it can be determined that local restrictions will divert such land uses to less safe sites to a degree that significantly compromises regional welfare. However, at least one state has included within a nonpoint pollution control program an administrative process-similar to the process used by some states in regard to hazardous waste facilities-to review any local disapproval or modification of a developer's nonpoint pollution control plan.94

\section{B. Socioeconomic Spillovers: Exclusionary Zoning}

State modification of overly restrictive local land use regulations has not received broad acceptance in existing pollution control programs, aside from hazardous waste facility siting legislation. However, certain states have been vigilant in invalidating excessive environmental land use controls in the context of exclusionary zoning. ${ }^{95}$

Exclusionary zoning operates, intentionally or unintentionally, to exclude from a community lower income residents or growth in general. ${ }^{96}$ The result is an adverse socioeconomic spillover consisting of harm to those who wish to gain admission to the community, and to those communities which host an unfairly large share of the excluded development. By invalidating excessive land use restrictions, the state imposes an obligation

93. See id. at 222-23.

94. See N.C. GEN. STAT. § 113A-61(c) (1983) (sediment pollution control).

95. See generally J. KUSHNER, FAIR Housing $\$ \S 7.08-7.10$ (1983) (discussion of exclusionary zoning).

96. Although growth controls often exclude lower or middle income families, see id. $\$ 7.07$, growth control cases center on exclusion of land uses rather than of certain classes of people. See Surrick v. Zoning Hearing Bd., 476 Pa. 182, 193 n.10, 382 A.2d 105, 110 n.10 (1977). 
on local units of government to bear a fair share of regional housing or development needs. ${ }^{97}$

Because localities often cite environmental problems in order to justify exclusionary zoning, state review of local environmental land use regulations can play a significant role in eliminating exclusionary zoning. The method states have used to eliminate exclusionary environmental land use regulations is quite similar to the method used to control excessive restrictions which cause environmental spillovers: The state requires restrictions to be tailored more closely to actual physical conditions when broader restrictions have undesirable regional effects. ${ }^{98}$ In both situations, the traditional deference to local land use restrictions is abandoned in favor of a heightened scrutiny approach: The need to maintain existing local health and safety restrictions is balanced against the regional interest in modifying the restrictions. ${ }^{90}$

In several major cases, courts have rejected claims by localities that potential groundwater and/or nonpoint source pollution problems justified exclusionary zoning restrictions. ${ }^{100}$ The fact that density restrictions are both an effective method of groundwater and nonpoint source pollution control $^{101}$ and a common means of exclusionary zoning ${ }^{102}$ suggests the po-

97. See, e.g., Southern Burlington County NAACP v. Township of Mount Laurel (Mount Laurel II), 92 N.J. 158, 456 A.2d 390 (1983) (fair share of regional lower income housing needs); National Land \& Inv. Co. v. Easttown Township Bd. of Adjustment, 419 Pa. 504, 215 A.2d 597 (1965) (fair share of regional demand for growth).

98. See Southern Burlington County NAACP v. Township of Mount Laurel (Mount Laurel II), 92 N.J. 158, 259, 456 A.2d 390, 441 (1983) (to extent necessary to meet Mount Laurel housing requirements, "municipalities must remove zoning and subdivision restrictions . . . that are not necessary to protect health and safety") (footnote omitted); National Land \& Inv. Co. v. Eastown Township Bd. of Adjustment, 419 Pa. 504, 526, 215 A.2d 597, 609 (1965) (instead of broad exclusionary zoning, more specific legislatively approved methods must be used to deal with groundwater pollution caused by growth).

99. At least one exclusionary zoning case has explicitly held that "closer scrutiny" must be applied to zoning provisions which "in addition to promoting legitimate zoning goals, also ha[ve] effects contrary to the general welfare." Home Builders League v. Township of Berlin, 81 N.J. 127, 139, 405 A.2d 381, 388 (1979). See also infra note 116.

100. See, e.g., Southern Burlington County NAACP v. Township of Mount Laurel (Mount Laurel I), 67 N.J. 151, 186, 336 A.2d 713, 731 (exclusion of lower income housing), appeal dismissed and cert. denied, 423 U.S. 808 (1975); Concord Township Appeal, 439 Pa. 466, 268 A.2d 765 (1970) (growth controls); National Land \& Inv. Co. v. Easttown Township Bd. of Adjustment, 419 Pa. 504, 525-26, 215 A.2d 597, 608-09 (1965) (same).

In Oakwood at Madison, Inc. v. Township of Madison, 72 N.J. 481, 371 A.2d 1192 (1977) (overruled on other grounds by Mount Laurel II , the plaintiff argued that carefully tailored controls could eliminate the water problems which Madison asserted in justification of its broad exclusionary restrictions. Id. at 544,371 A.2d at 1223 . The court endorsed the general principle of "tailoring." See id. at $512,544-45,371$ A.2d at $1207,1223-24$.

101. See supra note 31 . For cases in which large lot requirements were upheld for groundwater and/or nonpoint pollution control purposes, see, e.g., DeMars v. Zoning Comm'n, 142 Conn. 580, 115 A.2d 653 (1955); Moviematic Indus. Corp. v. Board of County Comm'rs, 349 So. 2d 667 (Fla. Dist. Ct. App. 1977); Bogert v. Township of Washington, 25 N.J. 57, 135 A.2d 1 (1957); Salamar Builders Corp. v. Tuttle, 29 N.Y.2d 221, 275 N.E.2d 585, 325 N.Y.S.2d 933 (1971); Caruthers v.

Board of Adjustment, 290 S.W.2d 340 (Tex. Civ. App. 1956).

102. See D. MANDELKER, ENvironment and Equity 80 (1981). 
tential for conflict between local water quality concerns and regional socioeconomic interests. But any type of cost-producing land use regulation has exclusionary potential. ${ }^{103}$ Thus the state should scrutinize local land use restrictions designed to control groundwater or nonpoint source pollution in order to identify when environmental concerns are used as a mere pretext for illegitimate exclusionary goals. ${ }^{104}$ In addition, the state should take steps to reconcile legitimate local environmental concerns with pressing regional needs by applying heightened scrutiny to local land use regulations that have the potential to restrict fulfillment of those needs. ${ }^{105}$

\section{The Need for Legislative Intervention}

The courts will not adequately control overregulation absent specific legislative direction. Standing requirements preclude many suits based on

103. See Southern Burlington County NAACP v. Township of Mount Laurel, 92 N.J. 158, 259, 456 A.2d 390, 441-42 (1983) (Mount Laurel II) (exclusionary zoning can be controlled by eliminating cost-generating restrictions not necessary to maintain minimum standards of health and safety); $R$. HeAly \& J. Rosenberg, supra note 44, at 25; Ellickson, Suburban Growth Controls: An Economic and Legal Analysis, 86 YALE L.J. 385, 391 (1977) ("Instead of placing numerical restrictions on the supply of housing, [a municipality] might impose burdensome development standards to inhibit housing construction.").

104. Noting that all development has some environmental impact, the court in Mount Laurel I cautioned that ecological concerns must not be used as "a makeweight to support exclusionary housing measures or preclude growth." Southern Burlington County NAACP v. Township of Mount Laurel (Mount Laurel I), 67 N.J. 151, 187, 336 A.2d 713, 731, appeal dismissed and cert. denied, 423 U.S. 808 (1975). The problem of pretext in the environmental context has received much scholarly attention. See, e.g., R. Healy \& J. RosenberG, supra note 44, at 25 (noting frequent use of "the rhetoric of the environmental movement . . . to mask more fundamental issues of class and race"); Delogu, supra note 46, at 285 ("The exclusion of . . . socially necessary undertakings is seldom done directly. . . Instead, when a municipality is confronted with a type of development it does not want ... it talks about potential environmental harm, traffic problems, soil and water limitations, and neighborhood impact.").

105. There are, of course, other environmental factors besides water pollution which are used to justify exclusionary zoning. Efforts to maintain subjective aesthetic values or "local character" are often an excuse for maintaining the exclusionary status quo. Thus, these factors should generally be accorded little value. See Southern Burlington County NAACP v. Township of Mount Laurel (Mount Laurel II), 92 N.J. 158, 277, 456 A.2d 390, 451 (1983); Vickers v. Township Comm., 37 N.J. 232, 269, 181 A.2d 129, 149 (1962) (Hall, J., dissenting), appeal dismissed and cert. denied, 371 U.S. 233 (1963); Delogu, supra note 46, at 286-88.

Objective factors deserving attention are limited in number. Mount Laurel $I I$ indicates that such considerations as suitability of terrain for development and preservation of water quality and prime agricultural land may justify restrictions on housing in communities which have not met their fair share obligations. Mount Laurel II, 92 N.J. at 311-12, 316, 456 A.2d 390, 469, 471. Restrictions enacted in response to legitimate objective concerns nevertheless should be scrutinized where they have the potential to cause regional harm. Of the factors mentioned in Mount Laurel II, water quality concerns are perhaps the least site specific and most technically oriented. Thus, local deference to state and federal standards is especially justified.

Tailoring land use regulations more strictly to physical conditions does not sacrifice environmental interests. Indeed, broad land use restrictions may be less effective than narrow restrictions which focus directly on the actual source of the problem. See D. Hoskins, Land Use, Water Quality and Ecosystem INTEGRTTY IN THE NEW JeRSEy Pinelands 57-58 (1984) (unpublished Environmental Defense Fund paper on file with author) (though control of nonpoint pollution of ground and surface waters could be achieved through increased lot sizes, requirement instead of more efficient septic system "may be politically, economically and ecologically more acceptable"). 
regional harms, especially when such suits are brought by nonresidents of the offending community. ${ }^{108}$ Although environmental land use regulation is a technically complex matter, zoning boards commonly are not required to make factual findings to justify their decisions. ${ }^{107}$ And because zoning is considered a legislative process, courts are generally deferent to zoning restrictions. ${ }^{108}$ When a challenge is premised on adverse regional consequences, the challenger faces an extraordinary burden of proof. ${ }^{109}$ Furthermore, the court may examine only the local impact of a restriction. That is, it may balance community benefit against only the harm done to the plaintiff instead of against the broader, regional harm. ${ }^{110}$ Or, the court may feel that accommodation of divergent local and regional interests is a policy matter best left to the legislature. ${ }^{111}$ Even if the challenge is successful, courts generally are neither willing ${ }^{112}$ nor able $^{113}$ to design and implement less restrictive regulations. ${ }^{114}$

State land use legislation can play a number of useful roles in eliminating excessive restrictions designed to control groundwater or nonpoint source pollution. The state can set up an administrative appeals process enabling expert state agencies, or other interested parties, to challenge local land use decisions. In addition, it can provide standards to help courts or administrative review agencies decide whether land use regulations are

106. See Note, The Land Use Policy and Planning Assistance Act of 1973: Legislating a National Land Use Policy, 41 Geo. WAsh. L. REv. 604, 607 \& n.29 (1973).

107. See D. MANDEL KER, supra note 102, at 32; see also DeMars v. Zoning Comm'n, 142 Conn. $580,584,115$ A.2d 653, 655 (1955) (upholding large lot requirement designed to protect groundwater despite absence of scientific support).

108. See Village of Euclid v. Ambler Realty Co., 272 U.S. 365, 388 (1926); 82 AM. JUR. 2D Zoning and Planning \$§ 25-30 (1976).

109. See Bosselman, Can the Town of Ramapo Pass a Law to Bind the Rights of the Whole World?, 1 FLA. ST. U.L. REv. 234, 253 (1973) ("herculcan burden" to demonstrate local, regional and state-as opposed to individual-ramifications of zoning).

110. In a few exclusionary zoning cases, courts have indicated that zoning ordinances which appear valid from a local standpoint may nevertheless be invalid because of adverse regional consequences. See Associated Home Builders v. City of Livermore, 18 Cal. 3d 582, 607, 557 P.2d 473, 487, 135 Cal. Rptr. 41, 55 (1976); Home Builders League v. Township of Berlin, 81 N.J. 127, 139, 405 A.2d 381, 388 (1979).

111. See, e.g., Construction Ind. Ass'n of Sonoma County v. City of Petaluma, 522 F.2d 897, 908 (9th Cir. 1975), cert. denied, 424 U.S. 934 (1976); Berenson v. Town of New Castle, 38 N.Y.2d 102, 111, 341 N.E.2d 236, 243, 378 N.Y.S.2d 672, 682 (1975).

112. Courts rarely mandate specific zoning revisions because they are reluctant to interfere with municipal legislative power. See D. MANDELKER, Environmental. and LAND Controls LegislaTION 6 (1976).

113. See Developments, supra note 46, at 1595 (courts possess "less expertise and fewer resources" than land use agencies for ensuring environmentally safe land use practices).

114. See, e.g., Southern Burlington County NAACP v. Township of Mount Laurel (Mount Laurel I), 67 N.J. 151, 186, 336 A.2d 713, 731 (court suggested, but did not mandate, less restrictive groundwater protection measures), appeal dismissed and cert. denied, 423 U.S. 808 (1975); National Land \& Inv. Co. v. Easttown Township Bd. of Adjustment, $419 \mathrm{~Pa}$. 504, 526, 215 A.2d 597, 609 (1965) (court noted existence of less restrictive legislatively approved methods of controlling groundwater pollution, but did not mandate use of such methods). 
in fact overly restrictive. ${ }^{116}$ Finally, state legislation can determine which regional interests deserve special consideration, and where within the state local efforts to control groundwater or nonpoint source pollution should be scrutinized for excessive restrictions on those regional interests. ${ }^{116}$ Heightened scrutiny may be prescribed in order to prevent diversion of pollutioncausing land uses to more sensitive areas, to prevent exclusion of growth or lower income housing, to protect farmland, ${ }^{117}$ or to protect other regional interests. ${ }^{118}$

115. See, e.g., Kasparek v. Johnson County Bd. of Health, 288 N.W.2d 511, 519 (Iowa 1980) (reliance on State Dep't of Health regulations to invalidate large lot requirement designed to protect groundwater); Southern Burlington County NAACP v. Township of Mount Laurel (Mount Laurel II), 92 N.J. 158, 259, 456 A.2d 390, 442 (1983) (building standards developed by federal government and by university research center "[p]articularly helpful, though in no way conclusive as to what the minimum standards should be in a particular community"); Concord Township Appeal, $439 \mathrm{~Pa}$. 466, 476-78, 268 A.2d 765, 769-70 (1970) (reliance on State Standards for Individual Sewage Disposal Systems to invalidate large lot requirement designed to prevent groundwater pollution).

116. Under Mount Laurel II, for example, the obligation to provide for a fair share of regional housing needs is imposed only upon communities within areas which the State Development Guide Plan designates as "growth." In such areas, once a plaintiff demonstrates that "the land use regulations fail to provide a realistic opportunity for low and moderate income housing," the burden shifts to the community to disprove or justify this failure. Southern Burlington County NAACP v. Township of Mount Laurel (Mount Laurel II), 92 N.J. 158, 222-23, 456 A.2d 390, 422 (1983). Thus, in effect, restrictions in growth areas receive heightened scrutiny. See also Board of Appeals v. Housing Appeals Comm. in the Dep't of Community Affairs, 363 Mass. 339, 365-67, 294 N.E.2d 393, 412-13 (1973) (for communities which have not met minimum obligation to provide lower income housing, state antiexclusionary statute requires housing boards of appeals to closely scrutinize local land use regulations to determine whether regional need for lower income housing outweighs local need for health, safety, or aesthetic restrictions).

Ordinary or relaxed scrutiny should be applied to groundwater and nonpoint pollution regulations where it is unlikely that such regulations will have a significant adverse effect on regional interests. For example, in Albano v. Mayor and Township Comm., 194 N.J. Super. 265, 476 A.2d 852 (N.J. Super. Ct. App. Div. 1984), the plaintiff challenged a large lot requirement adopted by a "nongrowth" community to control nonpoint pollution. Pollution control arguably could have been achieved through either a large lot size or a smaller lot size with supplementary protective measures. See id. at 271, 275-76, 476 A.2d at 854-55, 857. The trial judge apparently read Mount Laurel II to require lessened scrutiny of the large lot requirement because the township was in a nongrowth area. See id. at 273,476 A.2d at 856 . The appellate court affirmed the trial court's decision to allow the requirement to stand, though it did not reach the Mount Laurel II issue. Id. at 277,476 A.2d at 858 .

117. State efforts to protect farmland have restricted local use of agricultural land regulation to control groundwater and nonpoint pollution. See V. NovotNY \& G. ChESTERS, supra note 7, at 20 (nonpoint pollution); DiNovo \& Jaffe, supra note 30, at 6 (groundwater).

118. Austin, Texas, has imposed locally a land use program that accommodates many of the interests listed above in a manner similar to that suggested in this Note. Austin lies amongst several watersheds which are sensitive to nonpoint pollution of ground and surface waters. Development in all areas can be expected to contribute to the problem. The Austin watershed ordinances identify comparatively safe areas, and attempt to direct pollution-causing development to these areas. In one watershed, demand for growth is particularly high. Here, the ordinances impose "very specific and detailed stormwater engineering" instead of the broader density and development-prohibition regulations utilized in other watersheds. "These runoff controls substitute, in part, for restrictions that would limit development intensities." See DiNovo \& Jaffe, supra note 11, at 12-13. 


\section{State Land Use Regulation: A Gonclusion}

As suggested earlier, the local focus on amenity concerns rather than technical problems is a key cause of underregulation of land use practices which cause groundwater or nonpoint source pollution. ${ }^{119}$ Overregulation results largely from the same focus: Excessively stringent controls, such as overbroad health regulations or attempts to exclude growth or lower income housing, represent a departure from strictly technical concerns. But this does not necessarily mean that a local focus on amenity issues is undesirable. Local governments should retain primary responsibility for protecting local amenity values. ${ }^{120}$ Technical requirements, on the other hand, to the extent that they are overlooked by local governments, and to the extent that they are susceptible to standardization, ${ }^{121}$ are particularly appropriate objects of state concern. The state's role can largely be limited to supplementing local land use regulations with more restrictive technical requirements when underregulation has adverse regional effects and replacing local land use regulations with less restrictive technical requirements when overregulation has adverse regional effects. Such an approach may be essential if centralized land use regulation is to be politically acceptable. Technical issues, insofar as they are more "objective" than amenity issues, are an ideal focus for something as controversial as centralized land use regulation. ${ }^{122}$ It is precisely the narrow, technical focus of groundwater and nonpoint source pollution control that makes it an appropriate object of federal, as well as state, land use regulation. ${ }^{123}$

119. See supra text accompanying notes 47-51.

120. Cf. Little, Preservation Policy and Personal Perception: A 200-Million-Acre Misunderstanding, in LAND IN AMERICA 83, 84-85, 96-97 (R. Andrews ed. 1979) (indicating that centralized land use regulation may take an overly scientific approach to preservation of aesthetic values).

121. See id. at 84-85 (air and water quality more easily quantifiable than "land quality;" thus the former are more susceptible to state control than the latter).

122. See R. Healy \& J. Rosenberg, supra note 44, at 107-08 (California coastal planning commission focused initially on environmental problems rather than amenity problems such as recreation, appearance, transportation, and intensity of development, because the former were less controversial); Mandelker, The Quiet Revolution Reconsidered, LAND UsE L. \& ZoNING DiG., Aug. 1979, at 4,5 (state land use regulation demanded specific, relatively uncontroversial focus-protecting the environment-to be politically acceptable). But see Strong, Land as a Public Good: An Idea Whose Time Has Come Again, in The Land Use Policy Debate in the United States 217, 227 (J. de Neufville ed. 1981) (centralized land use regulation should be comprehensive rather than narrowly focused on water or air pollution control).

123. In the early 1970's, Congress gave extensive consideration to, but ultimately rejected, a National Land Use Planning Act (NLUP). This comprehensive Act was to provide several hundred million dollars in planning funds to participating states adhering to federal guidelines. See generally Note, supra note 106 (describing NLUP). The Coastal Zone Management Act, 16 U.S.C. \$\$ 1451-1464 (1982), enacted in 1972, utilizes an approach broadly analogous to that of NLUP, but is directed at a specific objective: protection of the coast. Though voluntary, all coastal states have participated. See R. JACkson, LAND USE IN AMERICA 57 (1981). See generally Caldwell, supra note 50, at 206 ("focus on specific land abuses might offer a more meaningful and acceptable approach to land use planning than general statutory authorization"). 


\section{The Federal Role}

The Clean Water Act declared war on water pollution. This war cannot be won without effective control of groundwater and nonpoint source pollution. Effective control is impossible absent land use regulation. The federal government should therefore acknowledge, encourage, and expand upon recent developments in state land use regulation to mobilize nationwide employment of land use regulation to control groundwater and nonpoint source pollution. Efforts must be made to break down the conservative bias of present land use law. ${ }^{124}$ At least for the purposes of groundwater and nonpoint source pollution control, land use regulation must be viewed as simply another tool with which to preserve water quality.

The fundamental federal role should be to promote state review of local regulations. Federal legislation must set forth procedural and substantive standards to guide state programs, and should provide for federal enforcement. ${ }^{125}$

Procedural standards should require the creation or employment of state agencies which have the authority to carry out a review program. These agencies must be able to develop land use guidelines for the control of groundwater and nonpoint source pollution, require local governments to prepare regulations corresponding to the guidelines, and take effective enforcement actions against noncompliant localities. ${ }^{126}$ Federal standards

124.

[W] hen rational, nonhistorical approches [sic] are made to present day land use problems, they often run head-on into a psychological wall of obdurate incompatible attitudes and behavior patterns. The intense emotional hostility with which many people react to almost any land use control measure cannot generally be explained wholly by reference to economic self-interest. Caldwell, supra note 50 , at 188 .

125. The federal government presently has no programs that directly require state or local land use regulation. See R. JAckson, supra note 123, at 60-61. The National Flood Insurance Program, 42 U.S.C. $\$ \S 4001-4128$ (1982), is perhaps the most extensive federal program which significantly penalizes communities which fail to conform their land use regulations to federal guidelines. See id. $\$$ 4102 (guidelines for land management and use). The Program directs federal agencies to deny federal financial assistance, and prohibit lending institutions from loaning money, to projects in areas with special flood hazards unless the community in which the area is located participates in the Program. Id. $\$ 4106$.

But the federal government is no stranger to using environmental programs to influence the allocation of authority over land use. By virtue of their control over the construction and location of sewers and sewage treatment plants, regional section 208 agencies have a considerable influence over local growth patterns. Sewer construction is perhaps the prime determinant of the location of development. See Council on Environmental QUaltTy, ThE Fifth ANNUAL Report of THE Council on ENVIRONMENTAL QUalTTY 36-39 (1974). Indeed, Congress clearly intended section 208 plans to affect land use and zoning plans. See S. REP. No. 414, 92d Cong., 2d Sess. reprinted in 1972 U.S. Code Cong. \& AD. News 3668, 3704; see also Godschalk \& Brower, supra note 46, at 161 (federal planning programs, including section 208, have "been the primary catalyst for institutionalizing a regional perspective").

126. Section 208 of CWA sets forth detailed requirements regarding the authority which agencies charged with implementing the provision must possess. 33 U.S.C. $\S 1288(c)(2)(A)-(I)(1982)$. The Coastal Zone Management Act (CZMA), which provides federal funding to support coastal land 
should require the agencies to have some means of controlling overregulation as well as underregulation. ${ }^{127}$

In regard to substantive requirements, the federal-state relationship should resemble the state-local relationship. ${ }^{128}$ The EPA should develop guidelines for state programs; if a state does not comply, the EPA must take enforcement measures. ${ }^{129}$ Most federal environmental legislation operates in this fashion. Federal guidelines should focus on promoting uniformity among the states to avoid pollution haven problems, ${ }^{130}$ and on preventing interstate environmental spillovers.

Federal enforcement efforts should primarily attempt to effect an appropriate disposition of state and local land use regulatory power. Direct federal land use regulation may be administratively burdensome and should be employed only as a last resort. Enforcement should take place in two steps. First, the EPA should make every effort to encourage states to develop and implement the program. Federal environmental grants of all kinds should be conditioned on adequate state performance.

Second, if a state refuses to develop an adequate state program pursuant to federal guidelines, the EPA should develop the state program. ${ }^{131}$ Conscriptive implementation of the program by ordering state or local governments to enact appropriate regulations, though potentially an effective approach, presents considerable political obstacles. ${ }^{132}$ The EPA there-

management programs meeting largely procedural federal guidelines, requires participant states to regulate land use in the coastal zone. If the state chooses not to directly regulate coastal land use, it must either establish "criteria and standards for local implementation, subject to administrative review and enforcement," or review local "development plans, projects, or land and water use regulations." 16 U.S.C. $\S 1455(e)(1)(1982)$.

127. CZMA requires participating states to provide a method of assuring that "local land and water use regulations within the coastal zone do not unreasonably restrict or exclude land and water uses of regional benefit." 16 U.S.C. $\$ 1455(\mathrm{e})(2)(1982)$.

128. See supra text accompanying note 56.

129. One version of the SDWA Amendments of 1986 proposed by the House of Representatives took a step in this direction in regard to groundwater. It required states to prepare for each underground source of drinking water plans which describe "the location and types of human development which affect the source and the types of such development which can occur without resulting in the degradation of such sources." S. 124, 99th Cong., 1st Sess. sec. 203, \& 1443A(a)(3) 131 ConG. REC. S9254 (daily ed. July 10, 1985). The state would then develop groundwater protection measures in accordance with these plans. Id. $1443 \mathrm{~A}(\mathrm{a})(4)$. This provision was eliminated from the final version of the Amendments.

130. State land use programs, like local programs, may be explicitly directed at promoting industrial and economic growth. See, e.g., MONT. CoDE ANN. \$ 90-1-101 (1985). Though of course such approaches are not inherently objectionable, they indicate that state land use programs may actually contribute to the pollution haven problem on an interstate level.

131. The EPA's lack of authority to develop section 208 plans if state efforts are inadequate is perhaps the biggest obstacle to effective federal enforcement of the land planning aspects of this provision.

132. This issue has been thoroughly treated in Stewart, supra note 53. Stewart's analysis is guided by the now overruled case of National League of Cities v. Usery, 426 U.S. 833 (1976), which held that Congressional commerce power violates the Tenth Amendment if it: (1) regulates the "States as States;" (2) addresses matters that are indisputably "attribute[s] of state sovereignty;" and (3) impairs the states' ability to "structure integral operations in areas of traditional governmental func- 
fore must rely on grant withholding sanctions and direct enforcement actions against violative land uses. It can withhold EPA funding from local units, ${ }^{193}$ or order the termination of all federal funding for projects located in sensitive areas, ${ }^{134}$ in order to encourage local governments to comply with the EPA's state guidelines. In addition, the EPA can proceed against specific pollution-causing land uses which violate state guidelines. For example, the EPA could withhold federal support from violative projects ${ }^{135}$ or negotiate agreements with government authorities which have control over potentially violative projects. ${ }^{138} \mathrm{Or}$, the EPA can exercise more direct control over land use by developing appropriate ambient standards and

tions." Id. at 845,852 . Nevertheless, Stewart concludes that federal conscription of state regulatory powers to control private parties may be constitutional under National League of Cities where federal suits "against individual polluters are too cumbersome and expensive to serve as a realistic alternative," and interstate environmental or economic spillovers are present. Stewart, supra note 53, at 1249-50. Federal intrusion into state sovereignty is justified in these circumstances because the existence of a spillover indicates a strong federal interest, and the fact that individual suits are too cumbersome shows that intrusion into state sovereignty is necessary to vindicate that federal interest. See Hodel v. Virginia Surface Mining \& Reclamation Ass'n, 452 U.S. 264, 288 n.29 (1981) (federal intrusion into state sovereignty is constitutional despite violation of three-pronged National League of Cities test if "the nature of the federal interest advanced [is] such that it justifies state submission"); see also Pennsylvania v. EPA, 500 F.2d 246, 261 (3d Cir. 1974) (EPA can compel exercise of state legislative and administrative powers to carry out federal Clean Air Act requirements because "[t]he states have, by their transportation policies, contributed to the problem of air pollution from automobile cmissions, and they can be required to take affirmative actions to correct it"). But see District of Columbia v. Train, 521 F.2d 971, 994 (D.C. Cir. 1975) ("mere fact that direct federal regulation of vehicles would be less 'efficient' would not appear sufficient to override the serious intrusion on state sovereignty involved" in EPA regulations requiring states to administer and enforce Clean Air Act provisions; thus such regulations violate Tenth Amendment), vacated and remanded sub nom. EPA v. Brown, 431 U.S. 99 (1977).

In the wake of Garcia v. San Antonio Metropolitan Transit Auth., 105 S. Ct. 1005 (1985) (overruling National League of Cities), it is presumably up to Congress rather than the courts to determine whether the federal government may order state or local governments to adjust land use regulatory practices in order to control groundwater and nonpoint pollution. See id. at 1018-21 (relying on national political processes to protect states' rights). But cf. Federal Energy Regulatory Comm'n v. Mississippi, 456 U.S. 742, 761-62 (1982) (Supreme Court "never has sanctioned explicitly a federal command to the States to promulgate and enforce laws and regulations . . ..").

133. The EPA has on occasion tried to use sewerage grant withholding to influence local land use plans. See Cape May Greene, Inc. v. Warren, 698 F.2d 179, 186-93 (3d Cir. 1983) (EPA grant condition aimed at stopping development in New Jersey coastal floodplain struck down because EPA lacked clear statutory authority and existing state land use regulation was adequate); Ellickson, supra note 103, at 435 (EPA sewerage construction grant withholding used as method of growth control).

134. For an example of such an enforcement approach used by the National Flood Insurance Program, see supra note 125.

135. "Federal support" includes both federal grants and federal contracts. The EPA currently can prohibit federal support in order to protect certain aquifers. See supra note 34. Most major land uses involve federal aid of some kind. Comment, The Environmental Protection Agency and Coastal Zone Management: Striking a Federal-State Balance of Power in Land Use Management, 11 Hous. L. REV. 1152, 1156 (1974).

136. In 1980, environmental groups filed a lawsuit alleging that highway construction in Florida would cause groundwater pollution by attracting residential and industrial development. Shortly thereafter, the EPA successfully sought re-evaluation by the Federal Highway Administration and the Florida Department of Transportation of the number and location of highway interchanges. See Florida Wildlife Fed'n v. Goldschmidt, 506 F. Supp. 350, 370-71 (S.D. Fla. 1981). 
vigorously policing violations due to land use practices, ${ }^{137}$ by imposing land management requirements on locally permitted land uses, ${ }^{138}$ or by banning the siting of certain pollution-causing land uses in sensitive areas. ${ }^{139}$

\section{CONCLUSION}

The narrow, relatively objective goal of groundwater and nonpoint source pollution control makes it an ideal object of federally mandated state land use regulation. Because the program proposed in this Note relies largely on local preparation of control plans pursuant to state guidelines, local governments are given the opportunity to reconcile the need to control groundwater and nonpoint source pollution with other local land use considerations. On the state level, the proposed review process will emphasize what many states have already realized: Local land use regulation has adverse regional effects which must be policed by the state. Finally, the federal government must mandate such a policing effort in order to fulfill the promise of the Clean Water Act. By requiring state control of local land use regulation, the federal government can ensure that the national water pollution problem is dealt with adequately and fairly.

137. Cf. Northwest Indian Cemetery Protective Ass'n v. Peterson, 764 F.2d 581, 588-89 (9th Cir. 1985) (action brought by private party in response to violation by silvicultural nonpoint pollution of ambient standards set forth in section 208 plan). Ambient standards are essentially performance standards, an increasingly popular method of land use regulation which allows development to proceed freely as long as it does not cause specified adverse effects. See Delogu, supra note 46, at 301-02.

138. The federal government already has authority in limited circumstances to prescribe land management requirements in order to control nonpoint pollution. See supra note 35.

139. The EPA may in fact need to promulgate some such bans as part of its federal guidelines. See generally South Terminal Corp. v. EPA, 504 F.2d 646, 677 (1st Cir. 1974) (under Commerce Clause, "EPA [is] free to promulgate rules that resemble local zoning ordinances"). 